\title{
Duplex DNA Capture
}

Vadim V. Demidov ${ }^{1}$, Nikolay O. Bukanov ${ }^{2}$ and Maxim D. Frank-Kamenetskii ${ }^{1}$

1Boston University, 36 Cummington Street, Boston Massachusetts 02215, USA

2Genzyme Genetics, 1 Mountain Road, Framingham, MA 01701-9322, USA

\begin{abstract}
This article describes the sequence-specific isolation and purification of intact double-stranded DNA (dsDNA) by oligonucleotide/PNA-assisted affinity capture (OPAC). The OPAC assay is based on selective tagging of a DNA duplex by biotinylated oligodeoxyribonucleotide (ODN) through formation of a so-called PD-loop. The PD-loop is assembled with the aid of a pair of PNA "openers", which allow sequence-specific targeting with a Watson-Crick complementary ODN probe in the exposed region of the dsDNA. The protocol involves three steps. First, two cationic bis-PNAs locally pry the DNA duplex apart at a predetermined site. Then, the exposed DNA single strand is targeted by a complementary biotinylated ODN to selectively form a stable PD-loop complex. Finally, the capture of dsDNA is performed using streptavidin covered magnetic beads. The OPAC procedure has many advantages in the isolation of highly purified native DNA over other affinity capture and amplification techniques.
\end{abstract}

\section{Introduction}

Methods for purification of specific dsDNA molecules from heterogeneous DNA mixtures or directly from biological samples have contributed immensely to molecular biology, genomics and the emerging field of DNA diagnostics. In many cases PCR amplification addresses the issues of DNA isolation and analysis. However, point mutations are often introduced during PCR amplification and information about post-synthetic (epigenetic) modifications of DNA nucleotides is lost. In addition, substances present in most samples of biological origin often inhibit PCR amplification.

In contrast to PCR, dsDNA affinity capture (1-11) allows for isolation of active and/or imprinted genes retaining all natural post-synthetic (epigenetic) modifications of DNA nucleotides without introducing point mutations. In general, affinity capture techniques do not interfere with specialized DNA sequences and have the potential to capture very large fragments of genomes. We describe here a new and efficient assay for dsDNA isolation and purification. Our approach, the ODN/PNA-assisted affinity capture (OPAC), makes it possible to isolate chosen DNA duplexes in the form of linear, non-supercoiled molecules.

It has recently been demonstrated that PD-loops (see Figure 1a) can be assembled sequence specifically with the aid of PNAs $(9,12)$. Formation of the PD-loop is based on the ability of short homopyrimidine PNAs to displace one strand of dsDNA forming a PNA-DNA-PNA triplex with the other strand (13-17). This exceptionally stable structure, known as a P-loop, is formed most readily with the use of positively charged bis-PNA (16-22). When a pair of such PNA "openers" bind to closely located homopurine DNA tracts separated by any short sequence of nucleobases, the two adjacent P-loops merge and an extended open region emerges inside dsDNA. This region can serve as a target for Watson-Crick binding of an ODN that cannot by itself form stable complexes with linear dsDNA, even near the end of the duplex (23).

Affinity capture of the targeted dsDNA fragments is possible by employing ODN probes with biotin or other tags that allow convenient capture. Figure $1 b$ shows a schematic of the steps in the OPAC method, in this case using streptavidin-coated iron microbeads for the capture of the dsDNA target fragment. The capture of the dsDNA occurs in a highly sequence-specific manner because only DNA sites opened by a pair of openers are accessible for binding with the Watson-Crick complementary ODN probe.

\section{Protocol}

\section{Materials}

Source of dsDNA molecules (mixture of dsDNA restriction fragments, plasmid cDNA library, etc.); a pair of short cationic bis-PNA "openers"; ODN probe/tag (typically about 15-nt-long) labeled with biotin, digoxigenin, etc.; affinity matrix (such as streptavidin- or antidigoxigenin-covered paramagnetic and agarose beads); separator (e.g., magnetic separator, microcentrifuge, chromatography column). The following buffer solutions are used: binding buffer (buffer A: 25 mM MES, pH 6.5), washing buffer (buffer B: PBS buffer, $\mathrm{pH} 7.5$ containing $1 \mathrm{mg} / \mathrm{ml} \mathrm{BSA}$ and $0.2 \mathrm{mg} /$ $\mathrm{ml}$ tRNA), immobilization buffer (buffer $\mathrm{C}$ : TAE buffer, $\mathrm{pH}$ 8.0 with $500 \mathrm{mM} \mathrm{NaCl}$ ), and elution buffer (buffer D: TE buffer, $\mathrm{pH} 7.5$ with 50 or $1,000 \mathrm{mM} \mathrm{NaCl}$ ). The last three buffers as well as the protocol below are applicable when a biotin-streptavidin capturing system and biomagnetic separation is employed (see Figure 1b). This protocol can be readily adapted to suit different experimental designs such as other ODN labeling groups and affinity matrixes. It is important in all instances to use siliconized micro-tubes to prevent the loss of sample DNA.

\section{Step 1: PNA targeting and ODN binding}

Incubate the DNA sample (typically $0.1-1 \mu \mathrm{g}$ ) with a pair of PNA "openers" in 10-20 $\mu \mathrm{l}$ of buffer A for about $10 \mathrm{~h}$ at $37^{\circ} \mathrm{C}$. A PNA concentration of $0.1-1 \mu \mathrm{M}$ is typically required depending on the binding affinity of the bis-PNAs. To avoid binding of unbound "openers" with the partially complementary ODN probe, remove excess PNA by gel filtration of the sample at room temperature through MicroSpin Sephadex G-50 column equilibrated with buffer A containing $200 \mathrm{mM} \mathrm{NaCl}$. Then incubate the sample for $1 \mathrm{~h}$ at $37^{\circ} \mathrm{C}$ to dissociate PNA bound with DNA nonspecifically. This will prevent non-selective dsDNA capture via associated PNA-ODN complexes. Next, bind about 1 pmol of biotinylated ODN in buffer A containing about 500 


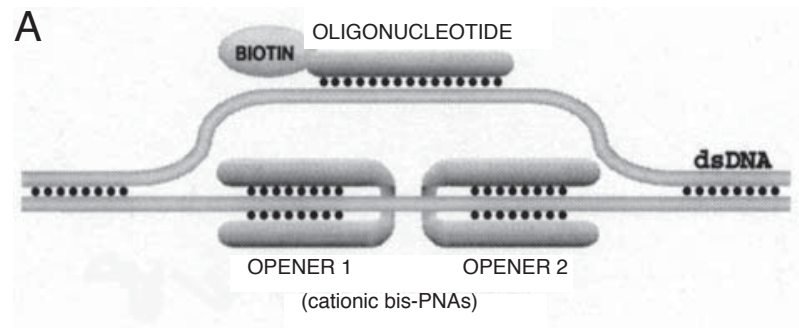

B

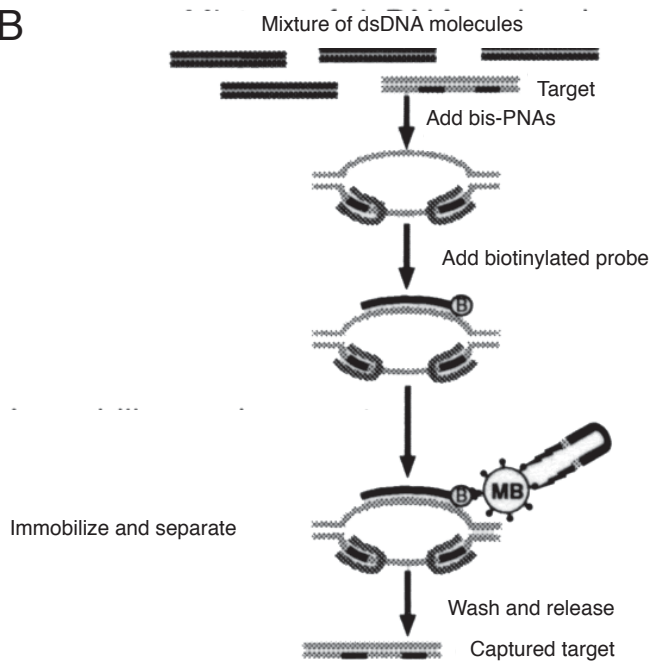

Figure 1. Basic principles of the OPAC selection procedure. A) The PDloop consists of duplex DNA, an ODN and two PNA "openers". The ODN binds to the complementary DNA target via Watson-Crick pairing and carries biotin to provide capture on the affinity support. B) The key steps of the OPAC procedure for dsDNA biomagnetic isolation. $(B=$ biotin, $M B=$ streptavidin coated magnetic beads).

$\mathrm{mM} \mathrm{NaCl}$ for $1 \mathrm{~h}$ at $37^{\circ} \mathrm{C}$. Remove free ODN from the sample by gel filtration in the same buffer at room temperature. A final volume about $30 \mu \mathrm{l}$ is convenient. After that incubate the sample for $1 \mathrm{~h}$ at $37^{\circ} \mathrm{C}$ to dissociate ODN tags bound with dsDNA non-specifically.

\section{Step 2: Magnetic Separation}

\section{Pre-Treatment of the Magnetic Beads}

Following the manufacturer's recommendation (24) resuspend the stock of magnetic beads, take $20 \mu \mathrm{l}$ of homogeneous suspension and collect the beads using a magnetic separator. Aspirate the supernatant and then add $250 \mu \mathrm{l}$ of buffer $\mathrm{B}$. Resuspend beads gently again and after 20 min collect the beads with the separator. Repeat the washing step with buffer $B$ and wash the beads twice in $250 \mu$ of buffer $\mathrm{C}$.

\section{Magnetic Separation}

Resuspend the beads in $20 \mu \mathrm{l}$ of buffer $\mathrm{C}$ and add $30 \mu \mathrm{l}$ of the DNA sample prepared during step 1. Incubate for 1-2 $\mathrm{h}$ at room temperature with occasional tipping to keep the beads suspended. Collect the beads using the magnetic separator, remove the supernatant, and wash magnetic beads at least two times with $250 \mu$ l of buffer $C$. Resuspend the beads in $150 \mu \mathrm{l}$ of buffer $\mathrm{C}$ and transfer suspension into another microtube. Collect the beads, discard the supernatant and then add $50 \mu \mathrm{l}$ of low- or high-salt buffer D. In low-salt buffer D, elution of dsDNA from the magnetic beads can be done by incubation of the sample with occasional gentle tipping for $20 \mathrm{~min}$ at about $45-50^{\circ} \mathrm{C}$. The temperature of the elution will depend on the binding affinity of an ODN probe, which is mostly determined by salt concentration, ODN length and ODN base composition. Under these conditions for dsDNA elution, the PNA "openers" remain bound to dsDNA. Up to five rounds of OPAC selection can be carried out without the timeconsuming re-targeting of DNA samples with the PNA "openers". Only the ODN tag needs to be rebound to facilitate the subsequent round of OPAC enrichment. If a single round of OPAC is enough for dsDNA selection or when it is necessary to remove bound PNA from DNA for subsequent manipulation with captured materials, high-salt buffer $\mathrm{D}$ should be used at the end of the procedure. In this case, incubate the sample at $65^{\circ} \mathrm{C}$ for $20 \mathrm{~min}$. Immediately thereafter collect the beads and transfer the supernatant containing the purified dsDNA fragment into the required buffer by gel filtration or ethanol precipitation to prepare for downstream applications.

\section{Example}

We have demonstrated the capability of the OPAC method by magnetic separation of a specific dsDNA fragment from a digest of the entire $S$. cerevisiae genome with the Mse I restriction enzyme (12). A unique 19-bp-long site we have

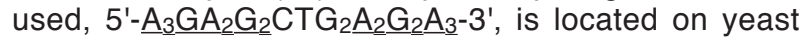
chromosome IX and consists of two homopurine targets for PNA "openers" (underlined) separated by 4-bp-long mixed purine-pyrimidine sequence. This site was targeted with the bis-PNA "openers", $\mathrm{H}(\mathrm{L} \text { ys })_{2}-\mathrm{T}_{3} \mathrm{JT}_{2} \mathrm{~J}_{2^{-}}\left(\mathrm{eg} 1_{3_{3}}\right.$ $\mathrm{C}_{2} \mathrm{~T}_{2} \mathrm{CT}_{3}-\mathrm{LysNH}_{2}$ (PNA 1; common abbreviations are used (18)) and $\mathrm{H}(\mathrm{Lys})_{3}-\mathrm{T}_{2} \mathrm{~J}_{2} \mathrm{~T}_{3}$-(eg1) $)_{3}-\mathrm{T}_{3} \mathrm{C}_{2} \mathrm{~T}_{2}-\mathrm{LysNH}_{2}$ (PNA 2). Affinity capture was performed with the use of a biotinylated 14-mer ODN probe; biotin- ${ }^{\prime} \mathrm{GA}_{2} \mathrm{G}_{2} \mathrm{CTG}_{2} \mathrm{~A}_{2} \mathrm{G}_{2} \mathrm{~A} 3^{\prime}$ (the 3'end of the ODN may also be used for biotinylation (12)). Model experiment (Figure 2a), which was done with the 863-bp-long target fragment amplified by PCR from yeast genome, demonstrated an efficient selection of desired dsDNA with its virtually complete recovery. Shorter, 12mer ODN tag did not allow us to capture the target fragment.

$250 \mathrm{ng}$ of yeast DNA (about $10^{7}$ genomic copies) was digested with the Mse I restriction enzyme and five rounds of the OPAC selection was performed. Note that the PNA "openers" were incubated with DNA only at the beginning of the first round as the low-salt buffer was used. The complexity of the original dsDNA pool was very high as the total number of different fragments was close to 40,000 . To assess the dsDNA purity, after each round a sample of the collected supernatant was analyzed by PCR amplification using a special adapter ligated to both ends of all fragments of the original digest as a primer (see ref. 12 for details). This assay amplified all captured DNA fragments and hence could be use to track the progress of the OPAC enrichment from step to step by gel electrophoresis.

After three rounds of selection, the complexity of the DNA pool was dramatically reduced (Figure $2 b$ ) and the desired 903-bp-long (863-bp-long target DNA plus two 20-bp-long adapters) dsDNA fragment could easily be isolated by gel electrophoresis. Additional rounds resulted in the isolation of the virtually pure target fragment (Figure $2 \mathrm{~b}$ lane 5). Restriction analysis and sequencing performed 
A non-
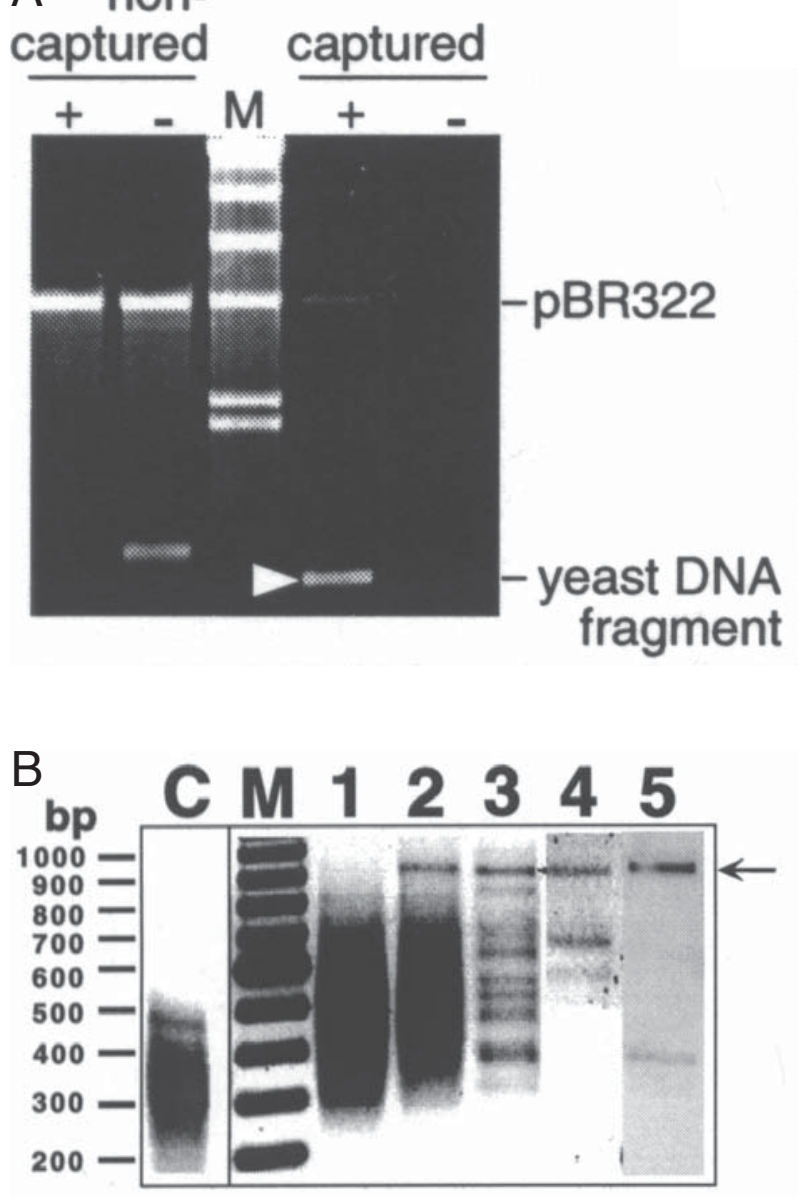

Figure 2. The OPAC selection of a specific fragment from yeast DNA ( $S$. cerevisiae strain $\mathrm{AB} 1380$ ) digested with the Msel restriction enzyme. After the OPAC procedure, the non-captured material and captured dsDNA released from the magnetic beads were analyzed by agarose gel electrophoresis.

A) Model experiment of the OPAC purification of a yeast DNA fragment. The mixture of a PCR-amplified yeast DNA fragment (a target) and linearized pBR322 plasmid (a control) was targeted with PNAs 1 and 2. Then, the capture procedure was performed in the presence $(+)$ or absence $(-)$ of the biotinylated ODN probe. The captured yeast DNA fragment is marked with the white arrowhead. In the absence of an ODN this fragment was not captured and had less mobility. The latter was due to cationic PNAs nonspecifically associated with the DNA fragment; these positively charged molecules dissociated from captured fragments during the washing procedure. $\mathrm{M}$ is for a $\lambda$ DNA HindlII digest used as size marker, where the lower doublet corresponds to $2.0-2.3 \mathrm{~kb}$.

B) The OPAC purification of a specific dsDNA fragment (arrow) from a Msel digest of the entire yeast genome (12). Lanes 1 through 5 correspond to one, two, three, four and five rounds of PD-loop formation/biomagnetic separation procedure, respectively. Lane $M$ is a 100-bp DNA ladder; lane $\mathrm{C}$ is the Msel digest of the yeast genome before capturing. A small portion of captured DNA collected after each round of enrichment was nonspecifically amplified for subsequent analysis by PCR (see ref. 12 for details). Note that PCR was only used as a detection method for following the enrichment. No intervening amplification of captured material was performed between the rounds.

after the 3rd and 5th rounds of OPAC confirmed that the DNA fragment marked by arrows in Figure $2 \mathrm{~b}$ was the requisite homogeneous fragment. The determined sequence of the captured DNA fragment was essentially identical to the corresponding sequence of $S$. cerevisiae deposited in the GenBank Database, with a few point substitutions. These point substitutions were different for fragments isolated after 3rd and 5th rounds and thus were acquired during the amplification or sequencing procedures. The target site was completely identical to the sequence from the $S$. cerevisiae Database and, therefore, was fully complementary to the PNA "openers" and the ODN tag used.

\section{Discussion}

The obtained results (ref. 12 and above) demonstrate that the OPAC technique is suitable for capturing specific fragments of duplex DNA from very complex mixtures of DNA. Just a few rounds of selection without any intermediate cloning or amplification procedures were sufficient to segregate the desired piece of DNA out of a very heterogeneous pool of dsDNA fragments. This is due to the remarkable sequence specificity of the OPAC assay. Note that single P-loops formed as a result of binding of separate PNA "openers" are too small to form stable complexes with an ODN. Therefore, only sites on dsDNA flanked by two specific "openers" are exposed and thus are accessible for hybridization to the complementary ODN probe. Most of DNA retains its duplex structure and is inaccessible for binding of an ODN with a mixed purinepyrimidine composition. Thus, the requirement of simultaneous binding of two "openers" along with an ODN probe to target dsDNA provides the extremely high selectivity of the OPAC method. It is also important that the entire PD-loop required for OPAC consists of about 20 bp or more and hence is unique within the entire human genome.

We anticipate that sequence restrictions inherent to the OPAC procedure due to the required homopyrimidine nature of PNA "openers" to be rather insignificant. Our data demonstrate that binding sites for "openers" can be as short as heptamers and that they can be separated by virtually an arbitrary sequence of nucleobases up to 10bp-long (12). Taking into account that probability to encounter any purine in DNA sequence is equal to $1 / 2$ and that a pair of adjacent homopurine stretches can be found in either strand of DNA duplex, such sites are met, statistically, after each (1/2) $2^{7+7} / 10 \sim 800 \mathrm{bp}$. In fact, sifting the GenBank Database available for several prokaryotic and eukaryotic genomes, we have found one site of that kind per several hundred base pairs, on average. Thus, normally each gene will carry an OPAC target site, especially in case of eukaryotes.

The situation is totally different from the triplex affinity capture (TAC) method (4-9). To provide an efficient capture of the DNA duplex, TAC requires a homopurinehomopyrimidine target region to be at least $20 \mathrm{bp}$ long. Such site occurs extremely rarely, statistically once every million base pairs. Therefore, TAC targets are normally not met in genes. The same is true for PNA-mediated affinity capture of long dsDNA stretches consisting of trinucleotide repeats (11).

The sequence limitations for the OPAC technique may be even less restrictive than indicated above. The ability of homothymine bis-PNA to target a complementary 5-bplong sequence within dsDNA via strand invasion has been recently reported (25) and hence implies that the targets for the PNA "openers" can be as short as pentamers. If 
they again can be separated by up to $10 \mathrm{bp}$, at least one site suitable for OPAC should be found every $50 \mathrm{bp}$ on average. Also, we have found that PD-loops can be formed when two closely located homopurine tracts are in opposite DNA strands (unpublished data). If PD-loops of that kind will be stable enough to be used for OPAC selection, this will further soften the OPAC sequence restrictions.

Future studies are necessary to understand the origin of the nonspecific dsDNA co-capture we encountered in the model OPAC experiments (12), as this limits the efficiency of the OPAC method. Our data indicate that random co-capture of nonspecific DNAs together with the targeted fragment may be caused by DNA aggregation through the positively charged PNA "openers". Therefore the optimal charge of PNA "openers" has to be determined to minimize nonspecific co-capture. Further investigations are also required to set the upper limits on the length of the OPAC isolated DNA fragments and on the complexity of the initial pool of DNA molecules which can be successfully enriched via the OPAC selection.

\section{Acknowledgements}

Support by the National Institutes of Health and PE Biosystems is appreciated.

\section{Note}

This article is a journal version of book chapter (26) reprinted by the publisher with the author's permission.

\section{References}

1. Honigberg, S.M., Rao, B.J. and Radding, C.M. 1986. Ability of RecA protein to promote a search for rare sequences in duplex DNA. Proc. Natl. Acad. Sci. USA. 83: 9586-9590.

2. Rigas, B., Welcher, A.A., Ward, D.C. and Weissman, S.M. 1986. Rapid plasmid library screening using RecA-coated biotinylated probes. Proc. Natl. Acad. Sci. USA. 83: 9591-9595.

3. Hakvoort, T.B.M., Spijkers, J.A.A., Vermeulen, J.L.M. and Lamers, W.H. 1996. Preparation of a differentially expressed, full-length cDNA expression library by RecA-mediated triple-strand formation with subtractively enriched cDNA fragments. Nucleic Acids Res. 24: 3478-3480.

4. Ito, T., Smith, C.L. and Cantor, C.R. 1992. Sequencespecific DNA purification by triplex affinity capture. Proc. Natl. Acad. Sci. USA. 89: 495-498.

5. Ito, T., Smith, C.L. and Cantor, C.R. 1992. Affinity capture electrophoresis for sequence-specific DNA purification. Genet. Anal. Tech. Appl. 9: 96-99.

6. Ji, H., Smith, L.M. and Guilfoyle, R.A. 1994. Rapid isolation of cosmid insert DNA by triple-helix-mediated affinity capture. Genet. Anal. Tech. Appl. 11: 43-47.

7. Sonti, S.V., Griffor, M.C., Sano, T., Narayanswami, S., Bose, A., Cantor, C.R. and Kausch, A.P. 1995. Large scale isolation of expression vector cassette by magnetic triple helix affinity capture. Nucleic Acids Res. 23: 3995-3996.

8. Wils, P., Escriou, V., Warnery, A., Lacroix, F., Lagneaux, D., Ollivier, M., Crouzet, J., Mayaux, J.F. and Scherman, D. 1997. Efficient purification of plasmid DNA for gene transfer using triple-helix affinity chromatography. Gene Ther. 4: 323-330.

9. Frank-Kamenetskii, M.D. 1999. Triplexes and biotechnology. In: Triple Helix Forming Oligonucleotides. C. Malvy, A. Harel-Bellan, and L.L. Pritchard, eds. Kluwer Academic Publishers, Boston, USA. pp. 285-294.

10. Shepard, A.R. and Rae, J.L. 1997. Magnetic bead capture of cDNAs from double-stranded plasmid cDNA libraries. Nucleic Acids Res. 25: 3183-3185.

11. Boffa, L.C., Carpaneto, E.M. and Allfrey, V.G. 1995. Isolation of active genes containing CAG repeats by DNA strand invasion by a peptide nucleic acid. Proc. Natl. Acad. Sci. USA. 92: 1901-1905.

12. Bukanov, N.O., Demidov, V.V., Nielsen, P.E. and FrankKamenetskii, M.D. 1998. PD-loop: A complex of duplex DNA with an oligonucleotide. Proc. Natl. Acad. Sci. USA. 95: 5516-5520.

13. Demidov, V., Frank-Kamenetskii, M.D., Egholm, M., Buchardt, O. and Nielsen, P.E. 1993. Sequence selective double strand DNA cleavage by PNA targeting using nuclease S1. Nucleic Acids Res. 21: 2103-2107.

14. Cherny, D. Y., Belotserkovskii, B. P., FrankKamenetskii, M. D., Egholm, M., Buchardt, O., Berg, R. H. and Nielsen, P. E. 1993. DNA unwinding upon strand displacement of binding of PNA to double stranded DNA. Proc. Natl. Acad. Sci. USA. 90: 16671670.

15. Demidov, V.V., Cherny, D.I., Kurakin, A.V., Yavnilovich, M.V., Malkov, V.A., Frank-Kamenetskii, M.D., Sönnichsen, S.H. and Nielsen, P.E. 1994. Electron microscopy mapping of oligopurine tracts in duplex DNA by peptide nucleic acid targeting. Nucleic Acids Res. 22: 5218-5222.

16. Betts, L., Josey, J.A., Veal, J.M. and Jordan, S.R. 1995. A nucleic acid triple helix formed by a peptide nucleic acid-DNA complex. Science. 270: 1838-1841.

17. Demidov, V. V., Yavnilovich, M. V., Belotserkovskii, B. P., Frank-Kamenetskii, M. D. and Nielsen, P. E. 1995. Kinetics and mechanism of polyamide ("peptide") nucleic acid binding to duplex DNA. Proc. Natl. Acad. Sci. USA. 92: 2637-2641.

18. Egholm, M., Christensen, L., Dueholm, K. L., Buchardt, O., Coull, J. and Nielsen, P. E. 1995. Efficient pHindependent sequence-specific DNA binding by pseudoisocytosine-containing bis-PNA. Nucleic Acids Res. 23: 217-222.

19. Griffith, M. C., Risen, L. M., Greig, M. J., Lesnik, E. A., Sprankle, K. G., Griffey, R. H., Kiely, J. S. and Freier, S. M. 1995. Single and bis peptide nucleic acids as triplexing agents: Binding and stoichiometry. J. Am. Chem. Soc. 117: 831-832.

20. Demidov, V. V., Frank-Kamenetskii, M. D. and Nielsen, P. E. 1996. Complexes of duplex DNA with homopyrimidine peptide nucleic acid (PNA): New principle of biomolecular recognition. In: Biological Structure and Dynamics (v. 2). R. H. Sarma and M. H. Sarma, eds. Adenine Press, Schenectady, USA. p. 129-134.

21. Veselkov, A. G., Demidov, V. V., Nielsen, P. E. and Frank-Kamenetskii, M. D. 1996. A new class of genome rare cutters. Nucleic Acids Res. 24: 2483-2488.

22. Kuhn, H., Demidov, V. V., Frank-Kamenetskii, M. D. and Nielsen, P. E. 1998. Kinetic sequence 
discrimination of cationic bis-PNAs upon targeting of double-stranded DNA. Nucleic Acids Res. 26: 582-587.

23. Kutyavin, I. V., Rhinehart, R. L., Lukhtanov, E. A., Gorn, V. V., Meyer, R. B., Jr. and Gamper, H. B., Jr. 1996. Oligonucleotides containing 2-aminoadenine and 2thiothymine act as a selectively binding complementary agents. Biochemistry. 35: 11170-11176.

24. Anonymous. 1992. Dynabeads Biomagnetic Separation System: Technical Handbook. Dynal AS, Oslo, Norway.

25. Armitage, B., Koch, T., Frydenlund, H., Ørum, H., Batz, H.-G. and Schuster, G.B. 1997. Peptide nucleic acidanthraquinone conjugates: Strand invasion and photoinduced cleavage of duplex DNA. Nucleic Acids Res. 25: 4674-4678.

26. Demidov, V.V., Bukanov, N.O., and Frank-Kamenetskii, M.D. 1999. Duplex DNA capture. In: Peptide Nucleic Acids: Protocols and Applications. P.E. Nielsen and M. Egholm, eds. Horizon Scientific Press, Wymondham, UK. p. 175-184. 


\section{Further Reading}

Caister Academic Press is a leading academic publisher of advanced texts in microbiology, molecular biology and medical research. Full details of all our publications at caister.com

- MALDI-TOF Mass Spectrometry in Microbiology Edited by: M Kostrzewa, S Schubert (2016) www.caister.com/malditof

- Aspergillus and Penicillium in the Post-genomic Era Edited by: RP Vries, IB Gelber, MR Andersen (2016) www.caister.com/aspergillus2

- The Bacteriocins: Current Knowledge and Future Prospects Edited by: RL Dorit, SM Roy, MA Riley (2016)

www.caister.com/bacteriocins

- Omics in Plant Disease Resistance Edited by: V Bhadauria (2016) www.caister.com/opd

- Acidophiles: Life in Extremely Acidic Environments Edited by: R Quatrini, DB Johnson (2016) www.caister.com/acidophiles

- Climate Change and Microbial Ecology: Current Research and Future Trend

Edited by: J Marxsen (2016)

www.caister.com/climate

- Biofilms in Bioremediation: Current Research and Emerging Technologies

Edited by: G Lear (2016)

www.caister.com/biorem

- Microalgae: Current Research and Applications Edited by: MN Tsaloglou (2016) www.caister.com/microalgae

- Gas Plasma Sterilization in Microbiology: Theory, Applications, Pitfalls and New Perspectives Edited by: H Shintani, A Sakudo (2016) www.caister.com/gasplasma

- Virus Evolution: Current Research and Future Directions Edited by: SC Weaver, M Denison, M Roossinck, et al. (2016) www.caister.com/virusevol

- Arboviruses: Molecular Biology, Evolution and Control Edited by: N Vasilakis, DJ Gubler (2016) www.caister.com/arbo

- Shigella: Molecular and Cellular Biology Edited by: WD Picking, WL Picking (2016) www.caister.com/shigella

-Aquatic Biofilms: Ecology, Water Quality and Wastewater Treatment

Edited by: AM Romaní, H Guasch, MD Balaguer (2016)

www.caister.com/aquaticbiofilms

- Alphaviruses: Current Biology

Edited by: S Mahalingam, L Herrero, B Herring (2016)

www.caister.com/alpha

- Thermophilic Microorganisms

Edited by: F Li (2015)

www.caister.com/thermophile
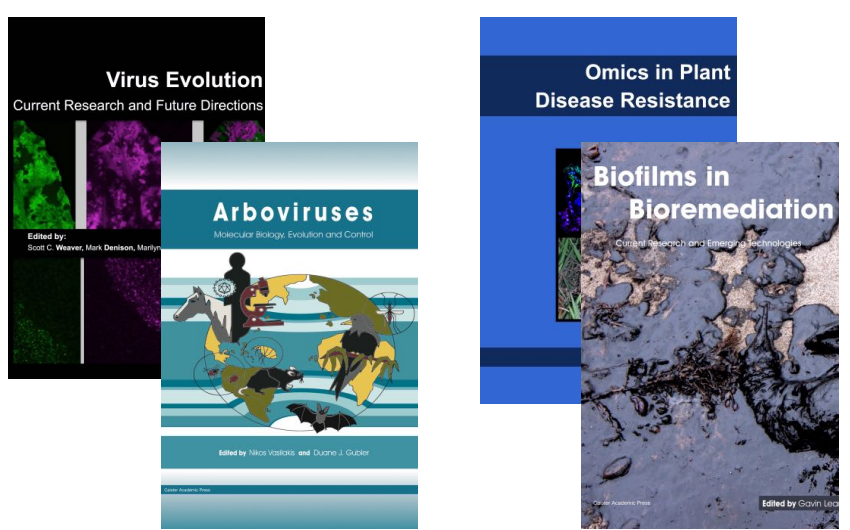
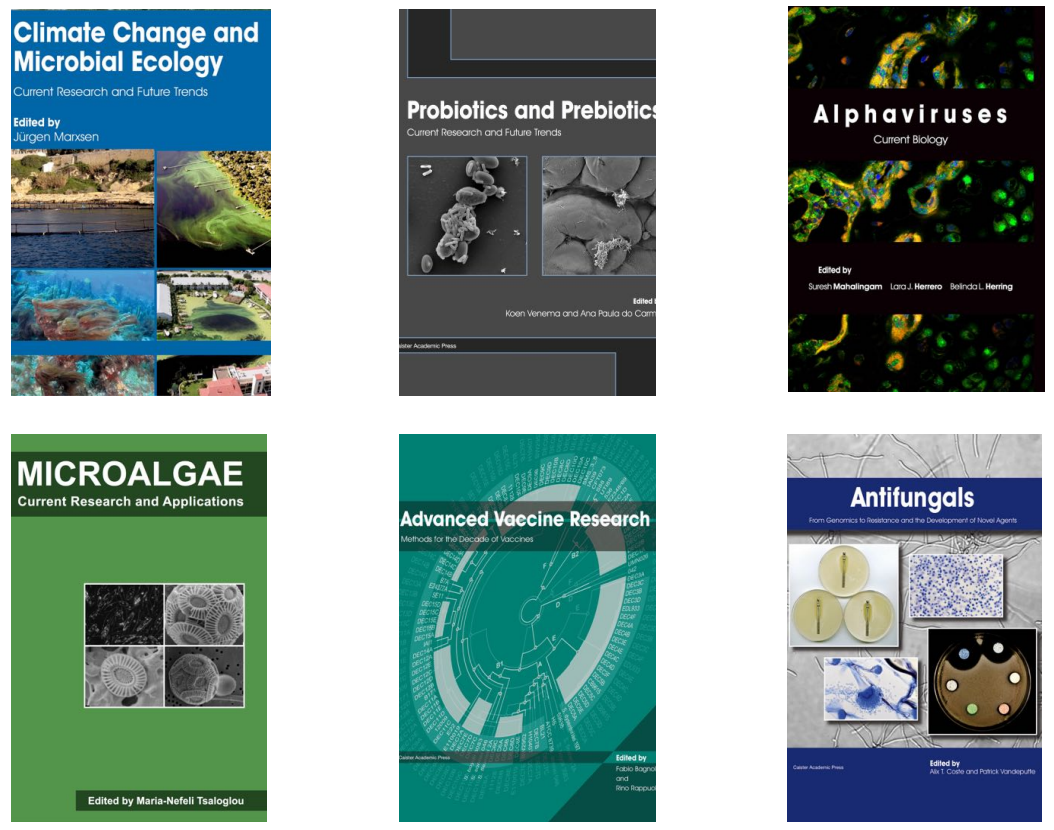

- Flow Cytometry in Microbiology: Technology and Applications Edited by: MG Wilkinson (2015) www.caister.com/flow

- Probiotics and Prebiotics: Current Research and Future Trends Edited by: K Venema, AP Carmo (2015) www.caister.com/probiotics

- Epigenetics: Current Research and Emerging Trends Edited by: BP Chadwick (2015) www.caister.com/epigenetics2015

- Corynebacterium glutamicum: From Systems Biology to Biotechnological Applications

Edited by: A Burkovski (2015)

www.caister.com/cory2

- Advanced Vaccine Research Methods for the Decade of Vaccines

Edited by: F Bagnoli, R Rappuoli (2015)

www.caister.com/vaccines

- Antifungals: From Genomics to Resistance and the Development of Novel Agents

Edited by: AT Coste, P Vandeputte (2015)

www.caister.com/antifungals

- Bacteria-Plant Interactions: Advanced Research and Future Trends Edited by: J Murillo, BA Vinatzer, RW Jackson, et al. (2015) www.caister.com/bacteria-plant

\section{- Aeromonas}

Edited by: J Graf (2015)

www.caister.com/aeromonas

- Antibiotics: Current Innovations and Future Trends

Edited by: S Sánchez, AL Demain (2015)

www.caister.com/antibiotics

- Leishmania: Current Biology and Contro Edited by: S Adak, R Datta (2015) www.caister.com/leish2

- Acanthamoeba: Biology and Pathogenesis (2nd edition) Author: NA Khan (2015)

www.caister.com/acanthamoeba2

- Microarrays: Current Technology, Innovations and Applications Edited by: Z He (2014)

www.caister.com/microarrays2

- Metagenomics of the Microbial Nitrogen Cycle: Theory, Methods and Applications

Edited by: D Marco (2014)

www.caister.com/n2 